\title{
Copper transporter 1, metallothionein and glutathione reductase genes are differentially expressed in tissues of sea bream (Sparus aurata) after exposure to dietary or waterborne copper.
}

\author{
M. Minghetti ${ }^{\mathrm{ab}}$, M. J. Leaver ${ }^{\mathrm{a}}$, E. Carpenè ${ }^{\mathrm{b}}, \mathrm{S}$. G. George ${ }^{\mathrm{a}}$ \\ ${ }^{a}$ Institute of Aquaculture, University of Stirling, Stirling FK9 4LA. \\ ${ }^{\mathrm{b}}$ Department of Biochemistry "G. Moruzzi", Veterinary Section, \\ Bologna University, Bologna, Italy.
}

Corresponding author: Dr M. J. Leaver, Institute of Aquaculture, University of Stirling, Stirling, FK9 4LA, United Kingdom.

Email: $\underline{\text { mj11@stir.ac.uk }}$

Tel: +44 (0)1786 467995

Fax: +44(0)1786 472133 


\begin{abstract}
The high affinity copper transporter $1(\mathrm{Ctr} 1)$, metallothionein (MT) and glutathione reductase (GR) are essential for copper uptake, sequestration and defense respectively. Following rearing on a normal commercial diet $\left(12.6 \pm 0.2 \mathrm{mgKg}^{-1} \mathrm{Cu}\right)$, sea bream were fed an experimental control diet lacking mineral mix $\left(7.7 \pm 0.3 \mathrm{mgKg}^{-1} \mathrm{Cu}\right)$, an experimental diet enhanced with $\mathrm{Cu}\left(135 \pm 4 \mathrm{mgKg}^{-1} \mathrm{Cu}\right)$ or an experimental diet $\left(7.7 \pm 0.3 \mathrm{mgKg}^{-1} \mathrm{Cu}\right)$ while exposed to $\mathrm{Cu}$ in water $\left(0.294 \pm 0.013 \mathrm{mgL}^{-1}\right)$. Fish were sampled at 0,15 and $30 \mathrm{~d}$ after exposures. Fish fed the $\mathrm{Cu}$-enhanced experimental diet showed lower levels of expression of $\mathrm{Ctr} 1$ in the intestine and liver compared to fish fed control experimental diets, whilst Ctr1 expression in the gill and kidney was unaffected by excess dietary $\mathrm{Cu}$ exposure. Waterborne $\mathrm{Cu}$-exposure increased $\mathrm{Ctr} 1 \mathrm{mRNA}$ levels in the intestine and the kidney compared to experimental controls. Excess dietary $\mathrm{Cu}$ exposure had no effect on levels of metallothionein (MT) mRNA, and the only effect of dietary excess $\mathrm{Cu}$ on glutathione reductase (GR) mRNA was a decrease in the intestine. Both MT mRNA and GR were increased in the liver and gill after waterborne $\mathrm{Cu}$ exposure, compared to levels in fish fed experimental control low $\mathrm{Cu}$ diets. Thus, $\mathrm{Ctr}$, MT and GR mRNA expression in response to excess $\mathrm{Cu}$ is dependent on the route of exposure. Furthermore, the tissue expression profile of sea bream $\mathrm{Ctr} 1$ is consistent with the known physiology of copper exposure in fish and indicates a role both in essential copper uptake and in avoidance of excess dietary and waterborne copper influx.
\end{abstract}

$\underline{\text { Keywords: }}$ copper, dietary copper, waterborne copper, Ctr1, gene expression, metallothionein, glutathione reductase, Sparus aurata

Footnote: The sea bream Ctr1 cDNA sequence has been deposited with the EMBL/Genbank database under accession number $\underline{\mathbf{A J 6 3 0 2 0 5}}$

\title{
Introduction
}

Copper is an integral part of many enzymes involved in diverse and vital biological processes and is therefore an essential trace element. Copper-dependent enzymes utilize the 
ability of copper to readily change its oxidation state from cuprous $\left(\mathrm{Cu}^{1+}\right)$ to cupric $\left(\mathrm{Cu}^{2+}\right)$ to catalyze fundamental redox reactions (Linder and Hazeghazam, 1996). However this same characteristic of copper ions can also lead to cytotoxicity through the production of highly damaging reactive oxygen species (ROS) and other free radicals which can cause catastrophic damage to lipids, protein and DNA (Halliwell and Gutteridge, 1984). Thus, all organisms have evolved sophisticated homeostatic mechanisms that regulate uptake, distribution, sequestration and export of copper (Prohaska and Gybina, 2004).

Fish represent a unique model among vertebrates because they can absorb copper through two routes: waterborne copper enters through the gills while dietary copper is absorbed through the intestine (Grosell and Wood, 2002). Diet is the main source of copper for fish under optimal growth conditions (Watanabe et al., 1997; Carpene et al., 1999), whereas waterborne copper can be absorbed through the gills in conditions of dietary copper deficiency (Kamunde et al., 2002). Farmed fish are fed diets supplemented with relatively high levels of $\mathrm{Cu}$ and $\mathrm{Zn}$ which have been empirically determined to maximise growth rate through the production cycle. Although attractive from a meat production viewpoint, little is known of the effects of such high $\mathrm{Cu}$ and $\mathrm{Zn}$ levels on fish health or on the environment surrounding farms. The importance of understanding the mechanisms of both essential and excess $\mathrm{Cu}$ uptake and effects in fish is highlighted by the observation that alarmingly high sediment $\mathrm{Cu}$ and $\mathrm{Zn}$ levels have been detected close to farming operations. This has been observed in both sea bream (Sparus aurata) aquaculture in the Mediterranean and Atlantic salmon aquaculture (Salmo salar) in Canada and Scotland (Chou et al., 2004; Mendiguchia et al., 2006; Dean et al., 2007). Sediment accumulation of $\mathrm{Cu}$ and $\mathrm{Zn}$ is largely due to the deposition of metal present in uneaten food and faeces and Cu levels of over $800 \mathrm{mgKg}^{-1}$, which considerably exceed the amount at which ecological effects may be predicted (Long et al., 1998), can be detected in the vicinity of fish cages (Dean et al., 2007). In order to resolve these issues it is necessary to both understand the mechanisms and regulation of essential dietary uptake by fish as well as the toxicological consequences of excess metal and environmental metal contamination.

The high affinity copper transporter 1 (Ctr1) is the principal candidate for mediating essential copper entry in eukaryotes. Ctr1 was first identified in yeast (Saccharomyces cervisiae) as the product of a gene essential for copper uptake and $\mathrm{CuZn}$-superoxide dismutase 
activity (Dancis et al., 1994). Subsequently homologous genes have been identified in mammals and have been shown to complement Ctr1 deficient yeast mutants (Zhou and Gitschier, 1997). Mammalian Ctr1 is able to mediate uptake of copper with high affinity and specificity in both human and mouse cells (Lee et al., 2001; Lee et al., 2002; Eisses and Kaplan 2005). Furthermore, mice with complete deficiency of Ctr1 die in utero following growth and developmental defects, whilst partially deficient heterozygous mice exhibit tissue specific defects in copper accumulation and in the activities of copper-dependent enzymes (Lee et al., 2001). Ctr1 has also been reported in zebrafish (Danio rerio) and knockdown of zebrafish Ctr1 mRNA results in embryonic lethality (Mackenzie et al., 2004). However, there have been no studies on the role of Ctr1 in copper uptake in fish. Metallothionein (MT) is a protein inducible by several toxic metals, including copper and zinc. It is also involved in copper and zinc storage and delivery and in free radical scavenging activity (Vasak, 2005; Selvaraj et al., 2005). Thus, MT is a vital component of both storage of essential metals and sequestration of toxic levels of $\mathrm{Cu}$, and has consequently gained popularity as a biomarker for environmental exposure to toxic metals (Hylland et al., 1992). Glutathione reductase (GR) is a ubiquitous enzyme, responsible for regulating homeostatic redox balance through the maintenance of reduced glutathione levels (Carlberg and Mannervik, 1985) and is induced in response to redox perturbation by a variety of agents including $\mathrm{Cu}$ (Hansen et al., 2006).

The aim of this study was to investigate the effects of excess $\mathrm{Cu}$ exposure to better understand the mechanisms of uptake and toxicity in a farmed marine fish, S. aurata. This was achieved by characterising Ctr1 in this species and by measuring the response of Ctr1, MT and GR mRNA expression to excess dietary or waterborne copper.

\section{Materials and Methods}

\section{Animals and treatments}

Juvenile gilthead sea bream average mass $40 \mathrm{~g}$ were obtained from farmed stock. One hundred fish were acclimatised for 15 days in a 15001 flow through tank at $19^{\circ} \mathrm{C}$ and at a salinity of $33.6 \pm 2.6 \%$. Before and during acclimatization fish were fed a pre-experimental normal commercial pelleted diet (Diet1; Skretting, Italy) at 2\% of body mass per day which

contained 12.6 $\pm 0.2 \mathrm{mgKg}^{-1} \mathrm{Cu}$ and $160 \pm 2.0 \mathrm{mgKg}^{-1} \mathrm{Zn}$ (Table 2). Fish were then divided into 
3 tanks of 1501 with 20 fish in each. In tank 1 fish were fed an experimental diet lacking mineral mix (Diet2) consisting of a pelleted diet prepared using $60 \%$ of fish meal, $20 \%$ of wheat middlings, $10 \%$ of soya meal, and $10 \%$ of fish oil and which contained $7.7 \pm 0.3 \mathrm{mgKg}^{-1}$ $\mathrm{Cu}$ and $60.1 \pm 04.1 \mathrm{mgKg}^{-1} \mathrm{Zn}$ (Table 2). Bulk ingredients to make the fish pellets were provided by Skretting and mixed with water. Mixing and extrusion were carried out with a commercial pasta maker and extruded diets were air dried and then chopped into pellets. The experimental diet with high $\mathrm{Cu}$ (Diet3) was produced by replacing water with an aqueous solution of $\mathrm{CuSO}_{4}$ to generate a final nominal dietary concentration of $130 \mathrm{mgKg}^{-1} \mathrm{Cu}(6.17$ $\mathrm{mM}$; Diet3) and this was fed to fish in tank 2. This sub-lethal level of dietary $\mathrm{Cu}$ was based upon a preliminary experiment where $120 \mathrm{mgKg}^{-1} \mathrm{Cu}$ was insufficient to elicit induction of MT (Carpenè unpublished data). Diets were then analyzed by atomic absorption spectrophotometry (AAS) to determine actual copper concentrations. Fish were fed at 1.5\% of body mass twice daily. In tank 3 fish were given Diet 2 and exposed to copper via water. Copper sulphate $\left(\mathrm{CuSO}_{4} \cdot 5 \mathrm{H}_{2} \mathrm{O}\right)$ was added to the tank to give a nominal $\mathrm{Cu}$ concentration of $0.3 \mathrm{mgL}^{-1}(1.2 \mu \mathrm{M})$. In a static renewal protocol $87 \%$ of the water was replaced with freshly prepared sea water containing $0.3 \mathrm{mgL}^{-1}$ copper sulphate, previously equilibrated in a testing chamber, every 24 hours for 30 days in waterborne treatment and with sea water only in control and diet tanks (tanks 1 and 2). The waterborne concentration of $\mathrm{Cu}$ was chosen based on the evidence of previous studies which indicated that this level of $\mathrm{Cu}$ was about $25 \%$ of the lethal concentration of $\mathrm{Cu}$ resulting in 50\% mortality after 96 hours for the closely related Sparus sarba (96h LC50 between 1.03 and $1.24 \mathrm{mgL}^{-1}$;(Wong et al., 1999). In addition, MT induction was demonstrated in the liver of sea bream at concentrations between 0.1 and 0.5 $\mathrm{mgL}^{-1}$ (Isani et al., 2003). Fish in waterborne exposure were also fed the control diet at 1.5\% of body mass twice each daily. $\mathrm{Cu}$ concentrations were verified by atomic absorption spectrometry (AAS). Fish were weighed before and after sampling and there were no differences in mean masses of animals subjected to copper treatments compared to controls at $15 \mathrm{~d}$ or at $30 \mathrm{~d}$ (Table 2 ).

At 0 days prior to treatment and after 15 days and 30 days seven fish chosen randomly from each tank were removed, sacrificed and tissues immediately sampled for RNA extraction and metal analysis. There were no mortalities in the tanks. Samples for RNA were immediately homogenised in TriReagent RNA extraction buffer (Sigma, UK) using a rotating probe 
homogeniser. Tissue samples for metal concentration were stored in acid washed ( $\mathrm{HCl})$ Teflon jars at $-20^{\circ} \mathrm{C}$.

\section{Metal determination}

Copper and zinc were determined in gills, intestine and liver tissues and also in the fish pellet and water. All polyethylene disposables were washed with $1 \mathrm{M} \mathrm{HCl}$. The samples were digested with $2 \mathrm{ml} \mathrm{65 \%} \mathrm{HNO}_{3}$ and $0.5 \mathrm{ml} \mathrm{30 \%} \mathrm{H}_{2} \mathrm{O}_{2}$ in a microwave oven (Model 1200, Milestone, Italy) for $5 \mathrm{~min}$ at $250 \mathrm{~W}, 5 \mathrm{~min}$ at $400 \mathrm{~W}, 5 \mathrm{~min}$ at $500 \mathrm{~W}$, and one min at $600 \mathrm{~W}$. Cooled samples were transferred into $10 \mathrm{ml}$ polyethylene volumetric flasks and directly aspired into the flame of an atomic absorption spectrophotometer (Model IL 11, Instrumentation Laboratory USA) equipped with a deuterium lamp background correction. The detection limit for copper was $6 \mathrm{ng} / \mathrm{ml}$; recovery ranged from $94 \%$ to $104 \%$. A trace metal standard was run every 20 samples. The accuracy of the method was evaluated by calibration to an international standard (CRM 278). The obtained concentration values fell within the confidence interval given by the Community Bureau of Reference, Brussels.

Sea water copper concentrations in tanks were determined by a Varian Atomic Absorption Spectrophotometer Mod. AA20plus equipped with a graphite furnace Mod. GTA96plus. Water analysis was performed after 50 times dilution of sea water to avoid salt interference. Using this method the detection limit for $\mathrm{Cu}$ was $5 \mu \mathrm{gL}^{-1}$ in seawater.

\section{$\underline{\text { Synthesis of sea bream Ctr1 cDNA }}$}

Total RNA was prepared using TriReagent (Sigma, UK) according to the manufacturers instructions, RNA quality was checked by spectrophotometry and agarose gel electrophoresis. cDNA was synthesised using $1 \mu \mathrm{g}$ of liver total RNA, $25 \mu \mathrm{M}$ of anchored oligo $\mathrm{dT}_{20}$ (Invitrogen, UK), $500 \mu \mathrm{M}$ dNTPs (Invitrogen, UK), 200units of SuperScript ${ }^{\mathrm{TM}}$ II RT reverse transcriptase with provided buffer (Invitrogen, UK). Reactions were incubated for 10 mins at $40^{\circ} \mathrm{C}$ followed by $42^{\circ} \mathrm{C}$ for 50 minutes in a final volume of $20 \mu 1$.

A partial Ctr1 cDNA was generated using PCR primers, Ctr1F1 and Ctr1R2 (Table 1), which were designed by selecting conserved areas from alignments of protein sequences derived

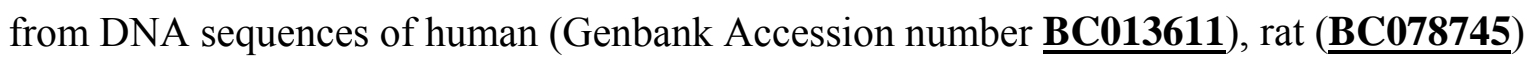
and zebrafish (NM 205717) Ctr1. Ctr1F1 and Ctr1R2 were included, at a concentration of 
$0.5 \mu \mathrm{M}$, in a reaction containing Taq polymerase with supplied buffer IV and $2 \mathrm{mM} \mathrm{MgCl}_{2}$ (Taq DNA Polymerase, ABgene, UK). One eighth $(2.5 \mu 1)$ of the cDNA synthesis reaction was included in a final volume of $25 \mu 1$. Annealing temperature was $52^{\circ} \mathrm{C}$.

RACE-PCR (Rapid Amplification of cDNA Ends) was performed using the FirstChoice RLM-RACE kit (Ambion,UK). Primers designed from the sequence of the initial partial cDNA (for 5' RACE 5'Ctr1-R1 and for 3'-RACE, 3'Ctr1F1; Table 1) were used to generate RACE amplicons.

The final full length PCR product was obtained using Ctr1Full-F and Ctr1Full-R (Table 1), designed from the 5' and 3' RACE products. The annealing temperature for all primers was $60^{\circ} \mathrm{C}$.

\section{$\underline{\text { Sequence analysis }}$}

Sequencing was performed using a Beckman 8800 autosequencer. Lasergene SEQman software was used to edit and assemble DNA sequences. The sea bream cDNA sequence was used to search pufferfish (Tetraodon nigroviridis), medaka (Oryzias latipes), stickleback (Gasterosteus aculeatus) and zebrafish genomes (www.ensembl.org) using TBlastX. Regions of chromosomal DNA sequence containing homologous sequences were then processed with GeneWise2 (www.ebi.ac.uk) using the sea bream deduced amino acid sequence as a key to generate predicted polypeptide sequences. ClustalW (Thompson et al., 1994) was used to generate multiple alignments of deduced protein sequences and to infer and bootstrap phylogenetic trees using the neighbour joining method (Saitou and Nei, 1987).

\section{Quantitative PCR}

All cDNA for quantitative PCR (QPCR) was synthesised using Superscript reverse transcriptase and supplied buffer components (Clontech, UK) and an oligo-dT containing primer (Table 1). Reactions contained $3 \mu \mathrm{g}$ of total RNA, 500ng oligo-dT primer in a volume of $20 \mu \mathrm{l}$ and were incubated at $42^{\circ} \mathrm{C}$ for 1.5 hours followed by $70^{\circ} \mathrm{C}$ for $15 \mathrm{~min}$. QPCR primers for target genes Ctr1, qCtr1F and qCtr1R, MT (U58774), qMT-F and qMT-R and GR ( $\underline{\mathbf{A J 9 3 7 8 7 3}})$, qGR-F and qGR-R and reference genes sea bream $\beta$-actin ( $\underline{\mathbf{X 8 9 9 2 0}})$, qActinF and qActinR, sea bream glyceraldehydes-6-phosphate dehydrogenase (GAPDH; ( $\underline{\text { DQ641630 }})$ qGapdhF and $q$ GapdhR and elongation factor $1 \alpha(\mathrm{EF} 1 \alpha ; \underline{\text { AF184170 }}) \mathrm{qEF} 1 \alpha \mathrm{F}$ 
and qEF1 $\alpha$ (Table 1) were used at $0.5 \mu \mathrm{M}$ with one fortieth of the cDNA synthesis reaction and SYBR-green QPCR mix (ABgene, UK) in a total volume of $20 \mu 1$. Reactions were run in a Techne Quantica thermocycler at an anneal temperature of $58^{\circ} \mathrm{C}$ for CTR 1 and $\mathrm{MT}, 55^{\circ} \mathrm{C}$ for $\beta$-actin and GR and $60^{\circ} \mathrm{C}$ for GAPDH and EF $1 \alpha$ to give a PCR product of $186,171,171,204$, 250 and 174bp respectively. Each QPCR product was than sequenced to confirm its identity and in each case was found to be identical to the predicted sequence. Gene copy number in each reaction was automatically calculated by the Quantica software by comparison to a standard curve constructed from the results of a parallel set of reactions containing serially diluted linearised plasmids containing sea bream CTR1, MT, GR, $\beta$-actin, GAPDH and EF1 $\alpha$ cDNA sequences. Concentrations of standards were determined spectrophotometrically and converted to copy number by consideration of plasmid size and DNA absorption coefficient. Normalisation of copy number across biological samples was achieved by using a normalization factor (NF) based on the geometric mean expression of reference genes $(\beta$ actin, GAPDH or EF1 $\alpha$ ) determined using geNorm software (Vandesompele et al., 2002). Within tissues, the stability of individual reference genes varied and geNorm was used to select the two most stable genes for a particular tissue, which were then used to normalize target gene expression level. Since the expression of all reference genes varied widely between tissues, the comparison of expression levels of Ctr1 in different tissues was achieved by normalising Ctr1 copy number to mass of total input RNA.

\section{$\underline{\text { Statistical analyses }}$}

Statistical analysis was performed using the Minitab v.15.1 statistical software package (Minitab Inc., USA). Data was first assessed for normality with the Kolmogorov-Smirnov test and for homogeneity of variances by Bartlett's test and examination of residual plots. Where necessary sample data was transformed to improve normality. Sample data was compared by analysis of variance (ANOVA) using a General Linear Model. Post hoc multiple comparisons were applied using Tukey's test (Zar 1999). A significance of $\mathrm{p}<0.05$ was applied to all statistical tests performed. All data are presented as mean \pm SD.

\section{Results}




\section{$\underline{\text { Sea Bream Ctr1 cDNA }}$}

Ctr1 has not been previously reported from sea bream and in this study it was important to isolate a full length cDNA to confirm its identity and to determine the expression profile of Ctr1 mRNA in different tissues. Following the first round of RT-PCR a DNA fragment of 376 base pairs was generated which, on sequencing, showed $88 \%$ identity to the zebrafish Ctr1 and 76\% identity to human Ctr1. To amplify the 5' end of the sea bream Ctr1 cDNA, two primers were synthesised based on the sequence of this fragment and used in a nested PCR procedure whereby a portion of the reaction mix after use of the 5'Ctr1-R1 was subjected to a further round of 5'-RACE using the 5' Ctr1-R2 primer. This yielded a fragment of 728 base pairs which overlapped with $100 \%$ identity with the original sequence. The 3'RACE using 3 Ctr1-F1 yielded a fragment of 398 bp which also showed 100\% identity with the original PCR product in the region of overlap. This allowed the inference of a full length cDNA for sea bream $\mathrm{Ctr1}$ ( $\mathrm{saCtr1}$ ) which consisted of an open reading frame of 222 amino acids and 5' end 3' untranslated regions of $197 \mathrm{bp}$ and $243 \mathrm{bp}$ respectively. To confirm the saCtr1 sequence primers (Ctr1Full-F and Ctr1Full-R) were designed to amplify the entire sea bream Ctr1 ORF. The sequence obtained (saCtr1) was 100\% identical to the assembled sea bream sequence and showed $78 \%$ identity with the human sequence and $89 \%$ with the zebrafish sequence.

Alignment of the deduced amino acid sequence of saCtr1 with Ctr1 proteins from other fish species, frog, lizard, chick and human show a strong sequence conservation, notably the MXM copper-binding motif, three trans-membrane domains and the C-terminal HCH motif (Puig et al., 2002; Guo et al., 2004; Guo and Petris, 2006; Fig. 1). Moreover, amino acids G34, N53, M69, K178 and D84 (of human Ctr1) which were shown by mutational analysis to affect $\mathrm{V}_{\max }$ and $\mathrm{K}_{\mathrm{m}}$ of copper uptake (Eisses and Kaplan, 2005) are completely conserved in sea bream and in all of the other vertebrate Ctr1 sequences, with the exception of lizard where a histidine residue in transmembrane domain 2 is replaced with aspartate (Fig 1).

In view of the possibility that fish species may contain multiple genes for which only single mammalian examples exist, the sea bream cDNA sequence was used to search for similar sequences in other fish genome sequences. In each species a single Ctr1 gene was identified and the Ctr1 derived from the zebrafish genome was identical to that previously described (Mackenzie et al., 2004). Furthermore phylogenetic comparison of all of the fish 
sequences with $\mathrm{Ctr} 1$ from other vertebrates indicated that the fish genes were monophyletic and that the sea bream Ctr1 was most closely related to the stickleback protein (Fig. 2).

The tissue expression profile of saCtr1 was determined by QPCR (Fig. 3). Of the eight tissues tested levels of Ctr1 mRNA were significantly higher in small intestine and gill than in kidney, liver, brain, heart, white and red muscle in which levels of Ctr1 mRNA were 6 to 10fold lower than in intestine.

\section{Growth and Metal levels in tissues}

Growth was not significantly affected by inclusion of $\mathrm{Cu}$ in the diet or in water after 15 days or after 30 days (Table 2).

$\mathrm{Cu}$ and $\mathrm{Zn}$ levels in fish tissues and diets are provided in Table 2. Cu levels in waterborne exposure tanks were $0.283 \pm 0.004 \mathrm{mgL}^{-1}$ at the beginning of the experiment and $0.294 \pm 0.013 \mathrm{mgL}^{-1}$ at the end of the experiment, whereas in control and dietary treatment tanks copper was $<0.005 \mathrm{mgL}^{-1}$ throughout the experiment.

$\mathrm{Cu}$ levels in all tissues examined from day 0 (Diet 1), day 15 and day 30 control fish (Diet2) were not significantly different. Copper levels in gill, intestine and liver of dietary exposed animals (Diet3; $135.5 \pm 4.4 \mathrm{mgKg}^{-1} \mathrm{Cu}$ dry diet) were not different from control animals at 15 days but after 30 days $\mathrm{Cu}$ accumulated in the liver (1.6 fold greater) and intestine (1.5 fold greater). After waterborne $\mathrm{Cu}$ exposure, gill $\mathrm{Cu}$ levels were higher at both 15 and $30 \mathrm{~d}$ timepoints, whilst hepatic $\mathrm{Cu}$ was higher at day 15 and had returned to control levels at day 30. Zn levels in liver and intestine from control fish sampled at 0, 15 and $30 \mathrm{~d}$ did not differ. Zn levels were reduced in the gills of control fish sampled at $30 \mathrm{~d}$, as well as those fish exposed to enhanced dietary and waterborne $\mathrm{Cu}$ for $30 \mathrm{~d}$, as compared to fish fed a commercial diet. In the liver of fish exposed to waterborne $\mathrm{Cu}$ for 30 days, $\mathrm{Zn}$ levels were lower compared to those in all other treatments. Due to a lack of tissue, metal levels were not determined in kidney.

\section{Effect of excess dietary and waterborne copper exposure on Ctr1, MT and GR gene expression}

Results are presented in Figure 4. Changing the control diets from Diet1 (preexperimental normal commercial diet) to Diet2 (reduced mineral mix) had no effect on intestinal, gill or kidney Ctr1 mRNA levels after 15 or $30 \mathrm{~d}$. Switching from Diet1 to Diet2 resulted in an increase of Ctr1 mRNA in the liver of control fish. After adding copper to Diet2 
(Diet3; $135 \pm 4.4 \mathrm{mgkg}^{-1} \mathrm{Cu}$ in diet) $\mathrm{Ctr1}$ mRNA levels were affected differently in different tissues. Intestinal Ctr 1 mRNA was 3.9 fold lower at $15 \mathrm{~d}$, however, at $30 \mathrm{~d}$, no significant decrease was detected (P-Value 0.0593) whilst Ctr1 levels were not affected in gill or kidney. In the liver of fish fed $\mathrm{Cu}$-enhanced diets (Diet3), Ctr1 mRNA decreased relative to Diet2 fed controls and returned to the levels measured in pre-experimental control fish at day 0 , which had been maintained on Diet1. After exposing fish on Diet2 to waterborne $\mathrm{Cu}$ for 30 days, intestinal and renal Ctr1 mRNA was higher than in controls on commercial Diet1 or on experimental control Diet2 alone. Hepatic Ctr1 mRNA did not change after waterborne $\mathrm{Cu}$ exposure relative to experimental controls on Diet 2.

Intestinal, gill and liver MT mRNA levels were lower in Diet2 fed control fish (15 and 30d) and in dietary and waterborne $\mathrm{Cu}$-exposed fish compared to Diet1 pre-experimental controls. There was no change in renal MT mRNA after switching control diets. Dietary $\mathrm{Cu}$ had no effect on MT mRNA relative to levels in control Diet2 in any of the tissues tested. In contrast waterborne exposure to $\mathrm{Cu}$ dramatically increased MT mRNA in liver relative to levels in Diet 1, Diet2 or Diet3 fish. Smaller but significant increases in MT mRNA were also measured in kidney and in gill after exposure to waterborne $\mathrm{Cu}$ relative to Diet 2 controls. Waterborne $\mathrm{Cu}$ had no effect on intestinal MT mRNA relative to Diet2 fed control fish.

Changing from Diet 1 to Diet2 had no effect on GR in gill, kidney or liver. Intestinal GR mRNA levels were decreased in experimental control fish after switching from Diet1 to Diet2, similar to effects observed on MT. Inclusion of $\mathrm{Cu}$ in either diet or water led to further reductions in intestinal GR mRNA. Dietary $\mathrm{Cu}$ had no effect on GR in gill or liver, but did lead to increases in kidney of diet 2 fed experimental control fish after 30 days. Waterborne $\mathrm{Cu}$ increased GR mRNA in gill and liver but had no apparent effect in kidney.

\section{Discussion}

In attempting to understand the mechanisms of $\mathrm{Cu}$ uptake in fish, whether under conditions of deficiency, sufficiency or excess, it is essential to consider known $\mathrm{Cu}$-specific transport proteins. Consequently we characterised the cDNA for the sea bream homologue of Ctrl, saCtrl. The deduced amino acid sequence of this cDNA possesses all of the domains that characterize Ctr1 in other species (Fig 2): the metal binding motif, the three 
transmembrane domains and the $\mathrm{HCH}$ motif. Moreover, the saCtr1 protein sequence possesses all of the amino acid residues shown to be essential for optimal Ctr1 activity (Eisses and Kaplan, 2005). The metal binding motif in the sea bream sequence differs from mammalian sequences in consisting solely of MXM (where X represents any amino acid residue) rather than the more extensive MXXMXM. However mutant mammalian Ctr1 proteins lacking the first methionine but containing either of the second or third methionines in the MXXMXM motif retain near maximal copper uptake activity (Puig et al., 2002). Based on phylogenetic and comparative genome analysis it is very unlikely that sea bream contain more than one Ctr1 gene. Therefore, considering the conserved structural features, comparative genome and phylogenetic analyses, it is most likely that the cDNA described here encodes a functional high affinity copper transporter, and has no other homologues in sea bream.

$\mathrm{Ctr} 1$ is essential for normal cellular $\mathrm{Cu}$ uptake and its expression is widespread among mammalian tissues (Kuo et al., 2001; Holzer et al., 2006) which would infer a primary role in systemic rather than dietary uptake. Ctr1 expression during zebrafish embryogenesis is mainly in the intestinal region after 24 hours and it continues to be strongly expressed in intestine until adulthood, when expression is more widespread (Mackenzie et al., 2004). In the present study we found that adult sea bream Ctr1 mRNA was also widely expressed, but most highly in intestine with levels some 4 to 10 fold lower in other tissues, consistent with results in other species. The role of $\mathrm{Ctr} 1$ in dietary uptake of $\mathrm{Cu}$ is unclear. $\mathrm{Ctr} 1$ is essential for absorption of $\mathrm{Cu}$ from the diet in neonates (Nose et al., 2006), but its expression has in some studies been localised to the basolateral membrane of intestinal cells, implying a role in delivering bloodborne $\mathrm{Cu}$ specifically for incorporation into intracellular intestinal proteins (Zimnicka et al., 2007) whilst in other studies Ctr1 is present on the apical membrane of intestinal cells (Kuo et al., 2006) consistent with a direct role in dietary $\mathrm{Cu}$ uptake. Since intestinal uptake of copper predominates in fish (Kamunde et al., 2002; Kamunde et al., 2001) this suggests a role for $\mathrm{Ctr} 1$ in uptake of dietary copper in fish, as in mammals. Indeed previous studies on $\mathrm{Cu}$ uptake in fish intestine provides evidence for the presence of a transporter with similar kinetics (high affinity/low capacity) to that of Ctr1 (Grosell and Wood, 2002; Burke and Handy, 2005) and our finding that Ctr1 mRNA is most highly expressed in intestine supports this contention. 
In this study, we focussed on the effect of excess $\mathrm{Cu}$ on gene expression during two possible routes of intake, diet and water. In order to generate control diets containing low copper, the mineral mix containing $\mathrm{Cu}, \mathrm{Zn}$ and other trace minerals was omitted resulting in an experimental control diet (Diet2) with $\mathrm{Cu}$ and $\mathrm{Zn}$ levels lower than the pre-experimental commercial diet (Diet1) which was used until the start of the experiment (day 0). Thus it is possible that effects on gene expression during exposure to high $\mathrm{Cu}$ may have been the result of lower levels of minerals other than $\mathrm{Cu}$. However, the low mineral experimental control diet (Diet2) did not cause reductions in the concentration of $\mathrm{Cu}$ and $\mathrm{Zn}$ in the tissues of control fish at $15 \mathrm{~d}$ or on growth rates, despite clear effects on gene expression. There were reductions in zinc in gill in all treatments after 30 days, although these reductions did not change the pattern of gene expression compared to 15 days, indicating that the reduction in dietary zinc was not a major factor in causing the differences in gene expression between fish fed the experimental diets. Furthermore, even though the level of $\mathrm{Zn}$ in the experimental control (60 $\mathrm{mg} \mathrm{Zn} \mathrm{kg}^{-1}$ ) diet was lower than that of the pre-experimental diet ( $\left.160 \mathrm{mg} \mathrm{Zn} \mathrm{kg}^{-1}\right)$, this level would not be considered deficient since the dietary $\mathrm{Zn}$ requirement for various fish species is known to range between 15 and $30 \mathrm{mg} \mathrm{kg}^{-1}$ (NRC 1993). Nevertheless, it is clear from the results that omission of mineral premix did affect gene expression in sea bream tissues, based on the differences seen between fish at day 0 , reared on the commercial diet, and fish at days 15 and 30 fed the experimental diets. The most pronounced effects were reductions in MT expression in intestine, gill and liver and reductions in GR in the intestine. These reductions were not subsequently reversed by inclusion of high $\mathrm{Cu}$ in the diet, in fact intestinal GR mRNA was further reduced by inclusion of high dietary $\mathrm{Cu}$. Therefore these effects on GR and MT are most likely to be caused by reductions in constituents of the mineral premix, other than $\mathrm{Cu}$. The most likely candidate constituent is $\mathrm{Zn}$, as it was reduced from 160 to $60 \mathrm{mg} \mathrm{kg}^{-1}$ in the control diets, whilst $\mathrm{Cu}$ was reduced to a much lesser extent, and MT is known to mainly respond to Zn status (Coyle et al., 2002). Thus, the relatively high level of MT and GR mRNA observed under normal commercial dietary conditions indicates that $\mathrm{Zn}$ levels may be excessive in this diet.

The effects of switching control diets on Ctr1 mRNA levels were distinct from effects on MT and GR. No effects on Ctr1 were observed in any control diets in intestine, gill and kidney, indicating that omission of the mineral premix is not a factor in considering the effects 
of excess $\mathrm{Cu}$ on this gene in these tissues. However, after dietary exposure to excess $\mathrm{Cu}$, sea bream exhibited up to a 4-fold decrease in intestinal Ctr1 mRNA with no associated increase in tissue $\mathrm{Cu}$ levels. This decrease may be a protective response to excess dietary $\mathrm{Cu}$, resulting in decreased $\mathrm{Cu}$-uptake. Previous studies on $\mathrm{Cu}$ uptake in fish have concentrated on the physiology of $\mathrm{Cu}$ distribution and have mainly considered the uptake and effects of copper in freshwater. Similar studies on marine species are few in number and there may be large differences in physiology between salt and freshwater fish. For example, in freshwater (low $\mathrm{Na}^{+}$) it is well established that copper uptake can occur through the $\mathrm{ENaC}$ sodium transporters of gill, although in conditions of high $\mathrm{Na}^{+}$concentrations, such as the seawater used here, these transporters are thought unlikely to play a significant part in either gills or gut (Handy et al., 2002). Even so, making use of the available data, the results presented here are consistent with a role for a high affinity carrier such as Ctr1 in regulating excess and normal copper uptake. Thus, $\mathrm{Cu}$-uptake exhibits kinetics in isolated rainbow trout (Oncorhynchus mykiss), consistent with the presence of Ctr1-like activity (Burke and Handy, 2005) and rainbow trout acclimated to $\mathrm{Cu}$ in the diet show increased $\mathrm{Cu}$ tolerance to both waterborne and subsequent dietary exposure (Miller et al., 1993). In another freshwater species, the catfish, Clarias gariepinus, $\mathrm{Cu}$ uptake across the gut has also been shown to be negatively regulated in isolated, perfused intestine, $\mathrm{Cu}$ uptake efficiency declining with increasing luminal $\mathrm{Cu}$ concentration (Handy et al., 2000). Additionally $\mathrm{Cu}$ absorption in rainbow trout reportedly declined with increasing dose of $\mathrm{Cu}$ infused into the intestine (Clearwater et al., 2000). Taken together these results strongly suggest that a specific high affinity $\mathrm{Cu}$-uptake system exists in freshwater fish intestine and that some component of this system may be down-regulated by exposure to excess dietary $\mathrm{Cu}$. Although sea bream is a marine species and not strictly comparable to freshwater models, the high expression levels of saCtr1 mRNA in intestine and the decreases induced by excess copper suggest that the $\mathrm{Cu}$-uptake component which is downregulated by excess $\mathrm{Cu}$ is $\mathrm{Ctr} 1$.

Waterborne $\mathrm{Cu}$ exposure showed very different effects on gene expression to dietary exposure. $\mathrm{Cu}$ levels were raised in the liver of fish after $15 \mathrm{~d}$ of waterborne exposure and returned to control levels at 30 days, despite dramatic induction of GR and MT at both timepoints. Large increases of GR were also observed in gill of fish exposed to waterborne $\mathrm{Cu}$. These effects are most likely a response to excess $\mathrm{Cu}$ exposure since the observed 
increases were not observed in low mineral mix control diets and were much higher than the levels observed on pre-experimental high Zn diets. Remarkably, and quite distinct from dietary exposure, waterborne $\mathrm{Cu}$ exposure also resulted in an increase in Ctr1 mRNA in sea bream intestine and in kidney after 30d. In freshwater rainbow trout, renal excretion of excess $\mathrm{Cu}$ in fish is negligible compared to hepatobiliary routes (Grosell et al., 1998) and although we did not measure copper levels in the kidney, marine fish, in contrast to freshwater species, can accumulate $\mathrm{Cu}$ in the kidney following brachial exposure, although at considerably lower levels than liver (Grosell et al., 2003; Grosell et al., 1997). Furthermore rainbow trout exhibit a rapid turnover of $\mathrm{Cu}$ in the kidney following brachial exposure (Grosell et al., 1997) indicating that, although accumulation may be low, the kidney is an important site of $\mathrm{Cu}$ transport and distribution in freshwater fish. Therefore the increase in Ctr1 mRNA in kidney is consistent with the observed low renal excretion of copper and with re-absorption by kidney. In conditions of copper scarcity renal Ctr1-dependent re-absorption may be an essential mechanism for maintaining optimal whole body copper concentrations. In conditions of excess copper it might be thought that renal excretion of copper in plasma filtrate would be an efficient way to remove $\mathrm{Cu}$. This is not the case and it may be that excess $\mathrm{Cu}$ is reabsorbed in the kidney, via increased $\mathrm{Ctr} 1$, as protection from renal toxicity which would otherwise be induced by an increased concentration of $\mathrm{Cu}$ in the tubules, an effect which would be particularly acute in marine fish which discharge a highly concentrated urine (Beyenbach, 2004). The increase in $\mathrm{Ctr} 1$ in intestine after waterborne- $\mathrm{Cu}$ exposure after $30 \mathrm{~d}$ is difficult to explain, particularly in the light of decreases in GR.

Considering the results in total it is clear that $\mathrm{Cu}$ has different effects on $\mathrm{Ctr} 1$, MT and GR mRNA expression depending on its route of uptake. Although we did not observe any effects, either of control diet or of waterborne $\mathrm{Cu}$ exposure on gill $\mathrm{Ctr} 1$, intake of $\mathrm{Cu}$ across the gill had very distinct effects on sea bream gene expression in other tissues compared to uptake across the intestine. Intestinal $\mathrm{Cu}$ uptake, although resulting in similar increases in tissue $\mathrm{Cu}$ levels, does not induce markers of toxicity such as MT or GR expression in liver or other tissues. This suggests that $\mathrm{Cu}$ from dietary sources is associated with different hepatic components or compartments than $\mathrm{Cu}$ from gill uptake, in turn inferring that the form in which $\mathrm{Cu}$ is delivered to the liver and other tissues must differ in some way between intestinal- and gill-derived $\mathrm{Cu}$. In mammals $\mathrm{Cu}$ uptake is entirely from the diet via the intestine, after which it 
enters the hepatic portal vein and progresses to the liver where it mixes with arterial blood and is taken up by hepatocytes. Within the hepatocyte a complex system of $\mathrm{Cu}$ chaperone proteins deliver $\mathrm{Cu}$ to various intracellular compartments and cupro-enzymes. In conditions of excess, $\mathrm{Cu}$ is excreted into the bile and at the same time intestinal uptake is reduced (Linder et al., 1998). Our results suggest that $\mathrm{Cu}$ in the hepatic portal vein derived from the intestine is likely to be complexed with a specific carrier enabling normal physiological uptake by liver cells. In contrast, $\mathrm{Cu}$ entering the arterial blood via the gill may be more likely to exist in a form which bypasses normal uptake and distribution pathways and thus causes induction of GR and MT, markers of redox and metal stress. To date three candidates for circulatory $\mathrm{Cu}$ transport have been suggested. Ceruloplasmin, a protein essential for iron homeostasis, contains up to $95 \%$ of $\mathrm{Cu}$ in the blood, but deficiency of the protein has no effect on $\mathrm{Cu}$ transport (Meyer et al., 2001). Similarly, deficiency of serum albumin, to which $\mathrm{Cu}^{2+}$ binds with high affinity, has no $\mathrm{Cu}$-transport or distribution effects (Vargas et al., 1994). Furthermore serum albumin binds $\mathrm{Cu}$ in a state which is not available for cellular uptake, although cells will take up $\mathrm{Cu}^{2+}$ complexed with L-histidine which in blood may couple albumin-bound $\mathrm{Cu}$ with cellular uptake systems (Deschamps et al., 2005). The third candidate is transcuprein (also known as $\alpha 2-$ macroglubulin and $\alpha 1$-inhibitorIII) and the bulk of copper derived from intestine and thence absorbed by liver is bound to this protein and to serum albumin with which it readily exchanges $\mathrm{Cu}^{2+}$ (Liu et al., 2007), although conclusive evidence for a central role in $\mathrm{Cu}$ transport is still lacking.

Although the decreases in sea bream intestinal Ctr1 mRNA and increases in kidney Ctr1 mRNA induced by dietary and waterborne $\mathrm{Cu}$ respectively may reflect an important protective adaptation to conditions of excess copper, in mammals the only known mechanism of Ctr1 regulation is post-translational (Kuo et al., 2006; Nose et al., 2006). However mammalian studies have concentrated on models of $\mathrm{Cu}$ deficiency and little attention has been paid to gene expression in models of $\mathrm{Cu}$ excess. In non-vertebrates more information exists. Yeast Ctrlp expression is controlled by Mac1p a transcription factor which both up-regulates $\mathrm{Ctr} 1 \mathrm{p}$ gene expression in conditions of $\mathrm{Cu}$-deficiency and represses $\mathrm{Ctr} 1 \mathrm{p}$ expression under conditions of $\mathrm{Cu}$ excess (Labbe et al., 1997). A Drosophila Ctrl homologue is up-regulated by copper depletion and this is dependent on MTF-1, a transcription factor which paradoxically also functions to up-regulate MT in conditions of excess $\mathrm{Cu}$ from species as diverse as insects 
and mammals (Selvaraj et al., 2005). The differential effects of $\mathrm{Cu}$ on sea bream liver following gill or intestinal uptake may provide a useful model in which to study the diverse transcriptional effects of $\mathrm{Cu}$ in vertebrates.

In summary, the tissue distribution profile and $\mathrm{Cu}$-dependent intestinal expression of sea bream Ctr1 mRNA is consistent with the physiological evidence from various fish species for the involvement of a functional high affinity transporter in copper homeostasis under conditions of both normal and excess dietary copper exposure. Furthermore, $\mathrm{Cu}$ derived from uptake via gill was associated with the induction of markers of metal toxicity, whilst uptake from intestine, using the synthetic diets used in this study, was not. In view of the potential for toxic metal contamination below aquaculture sites it is also notable that the concentration of $\mathrm{Zn}$ in a normal commercial diet may also result in increased MT in intestine and liver, indicating that dietary $\mathrm{Zn}$ levels might be excessive, from both fish health and environmental health viewpoints.

\section{References}

Beyenbach K.W., 2004. Kidneys sans glomeruli. Am. J. of Physiol., 286, F811-F827

Burke J., Handy R.D., 2005. Sodium-sensitive and -insensitive copper accumulation by isolated intestinal cells of rainbow trout Oncorhynchus mykiss. J. .Exp. Biol. 208, 391-407

Carlberg I., Mannervik B., 1985. Glutathione-reductase. Methods . Enzymol. 113, 484-490

Carpene E., Serra R., Manera M., Isani G., 1999. Seasonal changes of zinc, copper, and iron in gilthead sea bream (Sparus aurata) fed fortified diets. Biol. Trace Element Res. 69, 121-139

Chou C.L., Haya K., Paon L.A., Moffatt J.D., 2004. A regression model using sediment chemistry for the evaluation of marine environmental impacts associated with salmon aquaculture cage wastes. Mar. Poll. Bull. 49, 465-472

Clearwater S.J., Baskin S.J., Wood C.M., McDonald D.G., 2000. Gastrointestinal uptake and distribution of copper in rainbow trout. J. . Exp. Biol. 203, 2455-2466.

Coyle P., Philcox J.C., Carey L.C., Rofe A.M., 2002. Metallothionein: the multipurpose protein. Cell.. Mol. Life Sci. 59, 627-647.

Dancis A., Haile D., Yuan D.S., Klausner R.D., 1994. The Saccharomyces cerevisiae copper transport protein (ctr1p) - biochemical, characterization, regulation by copper, and physiological role in copper uptake. J. .Biol. Chem. 269, 25660-25667.

Dean R.J., Shimmield T.M., Black K.D., 2007. Copper, zinc and cadmium in marine cage fish farm sediments: an extensive survey. Env. Poll. 145, 84-95.

Deschamps P., Kulkarni P.P., Gautam-Basak M., Sarkar B., 2005. The saga of copper(II)-L-histidine. Coord. 
Chem. Rev. 249, 895-909.

Eisses J.F., Kaplan J.H., 2005. The mechanism of copper uptake mediated by human ctr1 - a mutational analysis. J.Biol. Chem. 280, 37159-37168.

Grosell M., Wood C.M., 2002. Copper uptake across rainbow trout gills: mechanisms of apical entry. J. Exp. Biol. 205, 1179-1188.

Grosell M., Wood C.M., Walsh P.J., 2003. Copper homeostasis and toxicity in the elasmobranch raja erinacea and the teleost Myoxocephalus octodecemspinosus during exposure to elevated water-borne copper. Comp. Biochem. Physiol. C. 135, 179-190.

Grosell M.H., Hogstrand C., Wood C.M., 1997. Cu uptake and turnover in both cu-acclimated and nonacclimated rainbow trout (Oncorhynchus mykiss). Aquatic Toxicol. 38, 257-276

Grosell M.H., Hogstrand C., Wood C.M., 1998. Renal cu and na excretion and hepatic Cu metabolism in both $\mathrm{Cu}$ acclimated and non acclimated rainbow trout (Oncorhynchus mykiss). Aquatic Toxicol. 40, 275-291.

Guo Y., Petris M.J., 2006. The functional study of histidine motif that regulates multimerization and copper stimulated endocytosis of human Ctr1 copper transporter. Faseb J. 20, A1366.

Guo Y., Smith K., Lee J., Thiele D.J., Petris M.J., 2004. Identification of methionine-rich clusters that regulate copper-stimulated endocytosis of the human ctr1 copper transporter. J. Biol. Chem. 279, 17428-17433.

Halliwell B., Gutteridge J.M.C., 1984. Oxygen toxicity, oxygen radicals, transition-metals and disease. Biochem. J. 219, 1-14.

Handy R.D., Eddy F.B., Baines H., 2002. Sodium-dependent copper uptake across epithelia: a review of rationale with experimental evidence from gill and intestine. Biochim. .Biophys. Acta-.. 1566, 104-115.

Handy R.D., Musonda M.M., Phillips C., Falla S.J., 2000. Mechanisms of gastrointestinal copper absorption in the African walking catfish: copper dose-effects and a novel anion-dependent pathway in the intestine. J. Exp. Biol.203, 2365-2377.

Hansen B.H., Romma S., Softeland L.I.R., Olsvik P.A., Andersen R.A., 2006. Induction and activity of oxidative stress-related proteins during waterborne cu-exposure in brown trout (Salmo trutta). Chemosphere 65, 17071714.

Holzer A.K., Varki N.M., Le Q.T., Gibson M.A., Naredi P., Howell S.B., 2006. Expression of the human copper influx transporter 1 in normal and malignant human tissues. J.Histochem., Cytochem. 54, 1041-1049.

Hylland K., Haux C., Hogstrand C., 1992. Hepatic metallothionein and heavy-metals in dab Limanda limanda from the German bight. Mar. Ecol.-Prog. Ser. 91, 89-96.

Isani I., Andreani G., Monari M., Carpene E. 2003. Metal concentrations (Cu, $\mathrm{Zn}$ and $\mathrm{Cd})$ and metallothionein expression in Sparus aurata exposed to waterborne copper. J. Trace Elements. Med. .Biol. 17, 17-23.

Kamunde C., Grosell M., Higgs D., Wood C.M., 2002. Copper metabolism in actively growing rainbow, trout (Oncorhynchus mykiss): interactions between dietary and waterborne copper uptake. J. Exp. Biol. 205, 279-290.

Kamunde C.N., Grosell M., Lott J.N.A., Wood C.M., 2001. Copper metabolism and gut morphology in rainbow trout (Oncorhynchus mykiss) during chronic sublethal dietary copper exposure. Can. J. Fish. Aquat. Sci. 58, 293305. 
Kuo Y.M., Gybina A.A., Gitschier J., Prohaska J.R., 2006. Copper transporter (Ctr1) expression in mouse tissue is impacted by age and dietary copper. Faseb J. 20, A553.

Kuo Y.M., Zhou B., Cosco D., Gitschier J., 2001. The copper transporter Ctr1 provides an essential function in mammalian embryonic development. Proc. . Nat. Acad. . Sci. USA 98, 6836-6841.

Labbe S., Zhu Z.W., Thiele D.J., 1997. Copper-specific transcriptional repression of yeast genes encoding critical components in the copper transport pathway. J.Biol. Chem. 272, 15951-15958.

Lee J., Pena M.M.O., Nose Y., Thiele D.J., 2002. Biochemical characterization of the human copper transporter Ctr1. J. .Biol. Chem. 277, 4380-4387.

Lee L.W., Prohaska J.R., Thiele D.J., 2001. Essential role for mammalian copper transporter Ctr1 in copper homeostasis and embryonic development. Proc..Nat. Acad. . Sci. USA 98, 6842-6847.

Linder M.C., Hazeghazam M., 1996. Copper biochemistry and molecular biology. Am. J.Clin. Nut. 63, S797S811.

Linder M.C., Wooten L., Cerveza P., Cotton S., Shulze R., Lomeli N., 1998. Copper transport. Am. J.Clin.Nut. $67,965 \mathrm{~S}-971 \mathrm{~S}$.

Liu N.M., Lo L.S.L., Askary S.H., Jones L., Kidane T.Z., Trang T., Nguyen M., Goforth J., Chu Y.H., Vivas E., Tsai M., Westbrook T., Linder M.C., 2007. Transcuprein is a macroglobulin regulated by copper and iron availability. J. Nut. Biochem. 18, 597-608.

Long E.R., Field L.J., Macdonald D.D., 1998. Predicting toxicity in marine sediments with numerical sediment quality guidelines. Env.Toxicol.Chem. 17, 714-727.

Mackenzie N.C., Brito M., Reyes A.E., Allende M.L., 2004. Cloning, expression pattern and essentiality of the high-affinity copper transporter 1 (Ctr1) gene in zebrafish. Gene 328, 113-120.

Mendiguchia C., Moreno C., Manuel-Vez M.P., Garcia-Vargas M., 2006. Preliminary investigation on the enrichment of heavy metals in marine sediments originated from intensive aquaculture effluents. Aquaculture 254, 317-325.

Meyer L.A., Durley A.P., Prohaska J.R., Harris Z.L., 2001. Copper transport and metabolism are normal in aceruloplasminemic mice. J.Biol.Chem.276, 36857-36861.

Miller P.A., Lanno R.P., Mcmaster M.E., Dixon D.G., 1993. Relative contributions of dietary and waterborne copper to tissue copper burdens and waterborne copper tolerance in rainbow trout (Oncorhynchus mykiss). Can. J.Fish. Aquat.Sci. 50, 1683-1689.

Nose Y., Kim B.E., Thiele D.J., 2006. Ctr1 drives intestinal copper absorption and is essential for growth, iron metabolism, and neonatal cardiac function. Cell Metab. 4, 235-244.

NRC. Nutrient Requirements of Fish, National Academy Press, Washington DC. 1993.

Prohaska J.R., Gybina A.A., 2004. Intracellular copper transport in mammals. J.Nut. 134, 1003-1006.

Puig S., Lee J., Lau M., Thiele D.J., 2002. Biochemical and genetic analyses of yeast and human high affinity copper transporters suggest a conserved mechanism for copper uptake. J.Biol.Chem. 277, 26021-26030

Saitou N., Nei M., 1987. The neighbor-joining method - a new method for reconstructing phylogenetic trees. 
Mol. Biol..Evol.4, 406-425.

Selvaraj A., Balamurugan K., Yepiskoposyan H., Zhou H., Egli D., Georgiev O., Thiele D.J., Schaffner W., 2005. Metal-responsive transcription factor (MTF-1) handles both extremes, copper load and copper starvation, by activating different genes. Genes Dev. 19, 891-896.

Thompson J.D., Higgins D.G., Gibson T.J., 1994. Clustal-W - improving the sensitivity of progressive multiple sequence alignment through sequence weighting, position-specific gap penalties and weight matrix choice. Nuc. Acid Res. 22, 4673-4680.

Vandesompele J., De Preter K., Pattyn F., Poppe B., Van Roy N., De Paepe A., Speleman F. Acurate normalizaton of real-time quantitative RT-PCR data by geometric averaging of multiple internal control genes. Genome Biol. 3, article 0034. 2002.

Vargas E.J., Shoho A.R., Linder M.C., 1994. Copper transport in the Nagase analbuminemic rat. Am. J.Physiol. 267, G259-G269.

Vasak M., 2005. Advances in metallothionein structure and functions. J.Trace Elements . Med. .Biol. 19, 13-17.

Watanabe T., Kiron V., Satoh S., 1997. Trace minerals in fish nutrition. Aquaculture 151, 185-207

Wong P.P.K., Chu L.M., Wong C.K., 1999. Study of toxicity and bioaccumulation of copper in the silver sea bream Sparus sarba. Env. International 25, 417-422

Zar J.H. Biostatistical Analysis, Prentice Hall International, New Jersey. 1999.

Zhou B., Gitschier J., 1997. hCtr1: a human gene for copper uptake identified by complementation in yeast. Proc. Nat. Acad. Sci. USA 94, 7481-7486.

Zimnicka A.M., Maryon E.B., Kaplan J.H., 2007. Human copper transporter hCtr1 mediates basolateral uptake of copper into enterocytes - implications for copper homeostasis. J.Biol.Chem.282, 26471-26480. 


\section{Tables}

Table 1. Primers used for cDNA isolation and QPCR.

\begin{tabular}{ll}
\hline ID & Sequence $5^{\prime} \rightarrow 3^{\prime}$ \\
\hline Ctr1F1 & gccgcaaatgaccttctactt \\
Ctr1F2 & ctacaactccatgcc \\
Ctr1R1 & ggcatggagttgtag \\
Ctr1R2 & actgccttcttccagctgaa \\
5'Ctr1-R1 & agcgatgcagaggtaagcgttgta \\
3'Ctr1-F1 & gctgatggagacgcacaagact \\
Ctr1Full-F & ctcgcgactttgtgagtttcgtgt \\
Ctr1Full-R & caaggtgttggttaccacggttac \\
qCtr1F & cgggtctgctcatcaacaccc \\
qCtr1R & tgtgcgtctccatcagcaccg \\
qMT-F & gctcctgcacctcctgcaag \\
qMT-R & gggtcacacacaggcgccat \\
qGR-F & caaagcgcagtgtgattgtgg \\
qGR-R & ccactccggagttttgcatttc \\
qActinF & gaccaactgggatgacatgg \\
qActinR & gcatacagggacagcacagc \\
qGapdhF & tgcccagtacgttgttgagtccac \\
qGapdhR & cagaccetcaatgatgccgaagtt \\
qEF1 $\alpha F$ & catggttgtggagccettct \\
qEF1 $\alpha R$ & tcctgcacgaccattcatttc \\
Oligo dT & aagcagtggtatcaacgcagagtactttttttttttttttttttttttttttnv \\
\hline
\end{tabular}


Table 2. Fish weights, copper and zinc tissue and diet concentrations at 0,15 and $30 \mathrm{~d}$ after exposure to dietary $\left(\mathrm{mgKg}^{-1}\right.$ dry mass) or waterborne $\left(\mathrm{mgL}^{-1}\right)$ copper.

\begin{tabular}{|c|c|c|c|c|c|c|c|}
\hline & $\begin{array}{l}\text { Day0 } \\
\text { Commercial } \\
\text { Diet }\end{array}$ & Day15 diet2 & Day15 diet3 & $\begin{array}{l}\text { Day15 } \\
\text { diet } 2+C u \text { in } \\
\text { water }\end{array}$ & Day30 diet2 & Day30 diet3 & $\begin{array}{l}\text { Day30 } \\
\text { diet2+Cu in } \\
\text { water }\end{array}$ \\
\hline Fish weights & $46.7 \pm 5.9$ & $51.1 \pm 8.2$ & $48.9 \pm 9.1$ & $51.6 \pm 6.6$ & $55.1 \pm 6.6$ & $52.3 \pm 9.8$ & $55.1 \pm 7.5$ \\
\hline $\operatorname{Diet}[\mathrm{Cu}]$ & $12.6 \pm 0.2$ & $7.7 \pm 0.3$ & $135.5 \pm 4.5^{*}$ & $7.7 \pm 0.3$ & $7.7 \pm 0.3$ & $135.5 \pm 4.5^{*}$ & $7.7 \pm 0.3$ \\
\hline Diet $[\mathrm{Zn}]$ & $160.0 \pm 2.0$ & $60.1 \pm 4.1$ & $67.6 \pm 2.3$ & $60.1 \pm 4.1$ & $60.1 \pm 4.1$ & $67.6 \pm 2.3$ & $60.1 \pm 4.1$ \\
\hline Gills [Zn] & $27.9 \pm 1.7$ & $33.5 \pm 3.2$ & $30.7 \pm 10.7$ & $33.3 \pm 4.3$ & $19.4 \pm 2.4^{*}$ & $19.1 \pm 7.3^{*}$ & $20.1 \pm 1.1^{*}$ \\
\hline Liver $[\mathrm{Cu}]$ & $5.4 \pm 2.0$ & $8.7 \pm 1.8$ & $8.9 \pm 1.4$ & $10.4 \pm 1.7^{*}$ & $8.5 \pm 2.3$ & $13.3 \pm 4.2^{*}$ & $8.5 \pm 2.6$ \\
\hline Liver $[\mathrm{Zn}]$ & $38.3 \pm 11.2$ & $61.1 \pm 29.1$ & $54.8 \pm 18.3$ & $44.3 \pm 18.6$ & $52.1 \pm 13.8$ & $40.0 \pm 17.0$ & $20.4 \pm 7.8^{*}$ \\
\hline Intestine $[\mathrm{Cu}]$ & $2.8 \pm 0.6$ & $3.2 \pm 0.4$ & $3.3 \pm 0.8$ & $3.1 \pm 1.1$ & $2.6 \pm 0.9$ & $3.9 \pm 0.8 *$ & $2.9 \pm 0.5$ \\
\hline Intestine [Zn] & $19.5 \pm 5.2$ & $22.5 \pm 0.5$ & $31.4 \pm 9.8$ & $26.4 \pm 15.3$ & $24.4 \pm 4.2$ & $31.3 \pm 13.6$ & $21.8 \pm 6.1$ \\
\hline
\end{tabular}

Values are means \pm S.D. $n=5$, asterisks indicate a significant $(\mathrm{P}<0.05$; ANOVA, Tukeys test $)$ difference from control experimental diet at day 15 or day 30 . Copper and zinc content in the tissues diet and water was determined by AAS. 


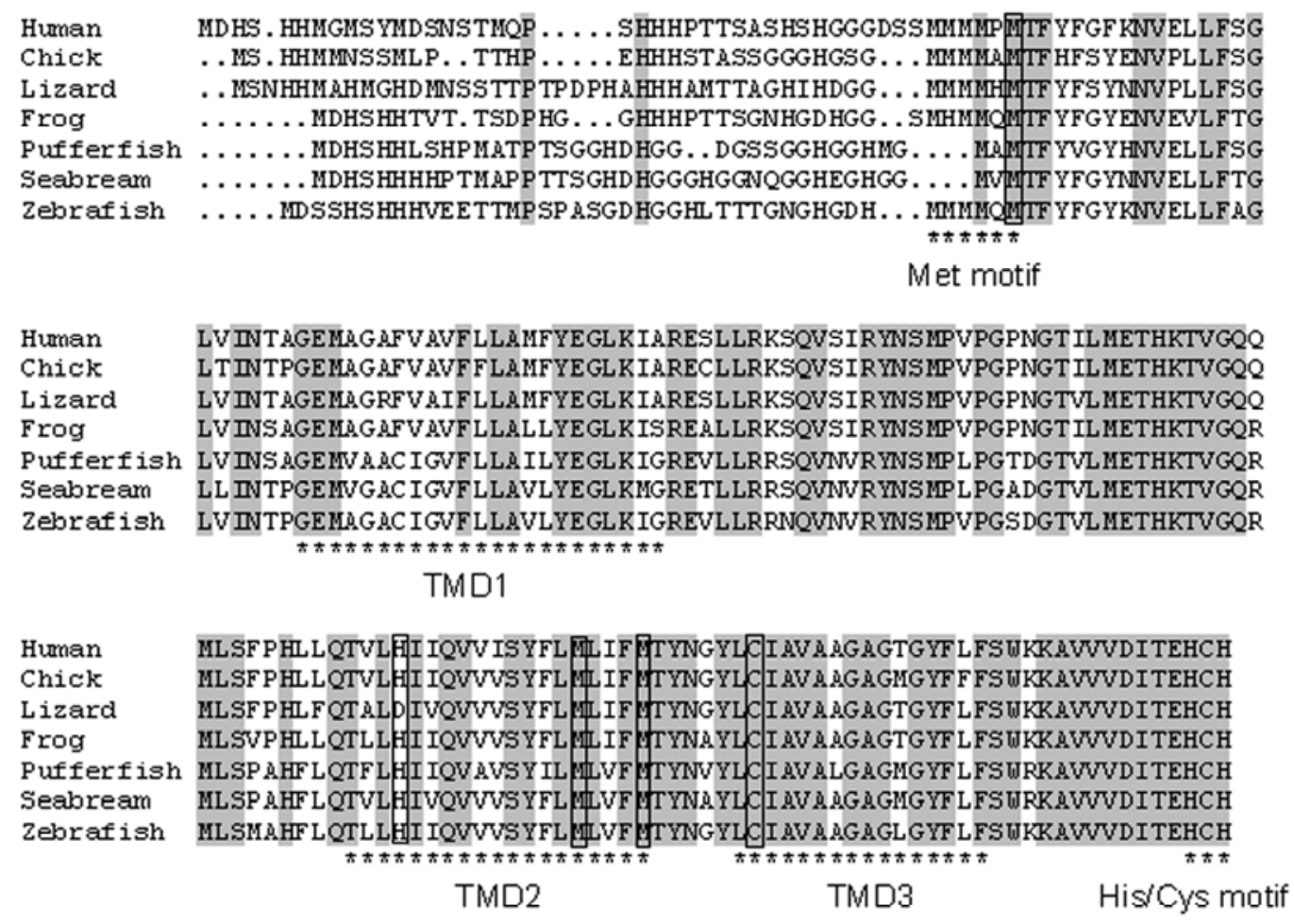

Figure 1. Alignment of vertebrate Ctr1 polypeptide sequences.

Residues identical in all proteins are shaded. The positions of the conserved methionine-rich copper binding motif (Met motif), transmembrane domains (TMD1-3) and the C-terminal $\mathrm{HCH}$ motif referred to in the text are indicated. The residues shown to be required for the activity of human Ctr1 are boxed 


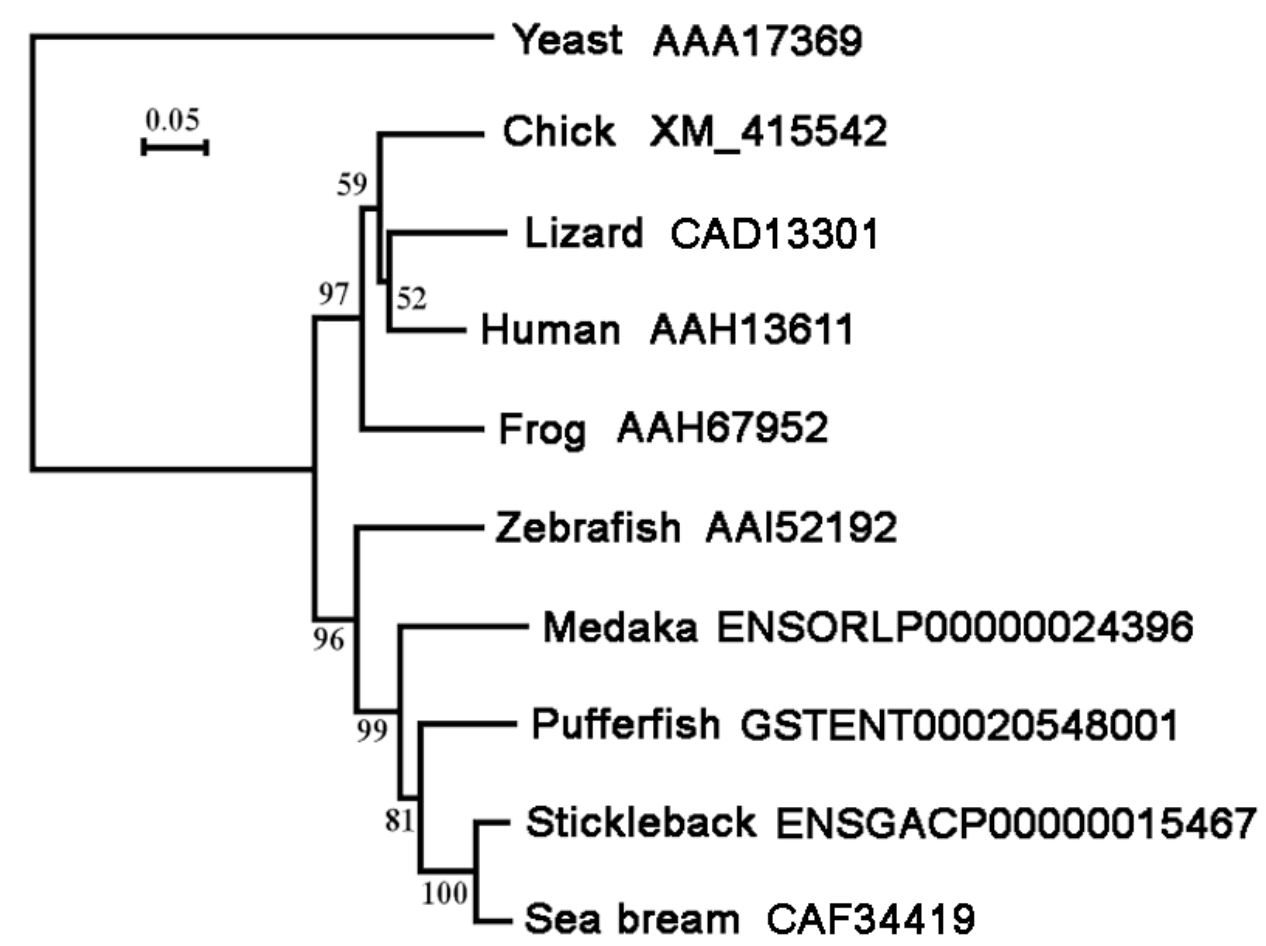

Figure 2. Phylogenetic relationships of vertebrate Ctr1 polypeptide sequences.

Sea bream (Sparus aurata), medaka (Oryzias latipes), stickleback (Gasterosteus aculeatus), zebrafish, (Danio rerio), pufferfish, (Tetraodon nigroviridis) along with human, frog, (Xenopus tropicalis) lizard, (Podarcis sicula), chick (Gallus gallus) and yeast (Saccaromyces cerevisae) Ctr1 were used to generate the phylogenetic tree using ClustalW. Numbers (bootstrap values) represent the percentage of times the associated branch topology was returned after 1000 iterations of tree generation. The Genbank accession numbers or the ENSEMBL peptide ID for the protein sequence of each species is provided. 


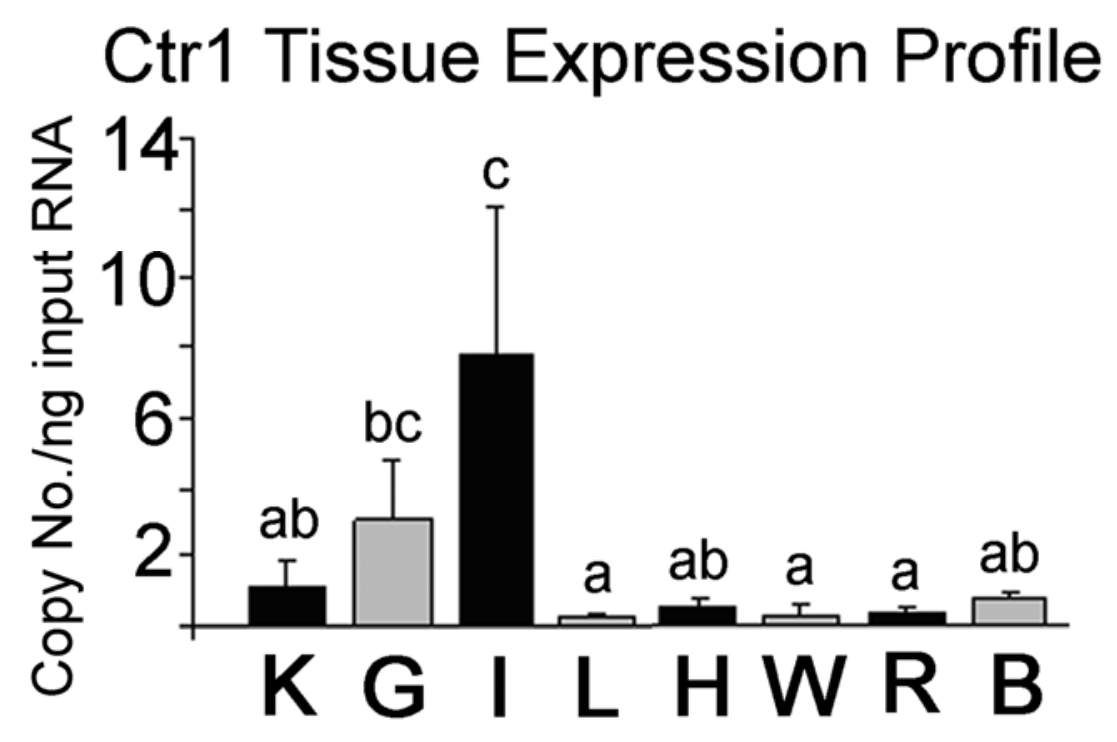

Figure 3. Tissue expression profile of saCtr1 mRNA in sea bream fed a commercial diet. Data are presented as mean \pm standard deviation ( $\mathrm{n}=5$ fish/replicate). Means bearing different lettering are significantly different between tissues $(\mathrm{p}<0.05$, ANOVA, Tukeys test). Data shown are day 15 Diet2 fish. L, liver; K, kidney; G, gill; I, intestine; B, brain; W, white muscle; $\mathrm{R}$, red muscle; $\mathrm{H}$, heart. "The data shown represent the fish fed Diet $2(7.7 \pm 0.3 \mathrm{mgKg}$ ' ${ }^{1} \mathrm{Cu}$ ) for $15 \mathrm{~d}$. 


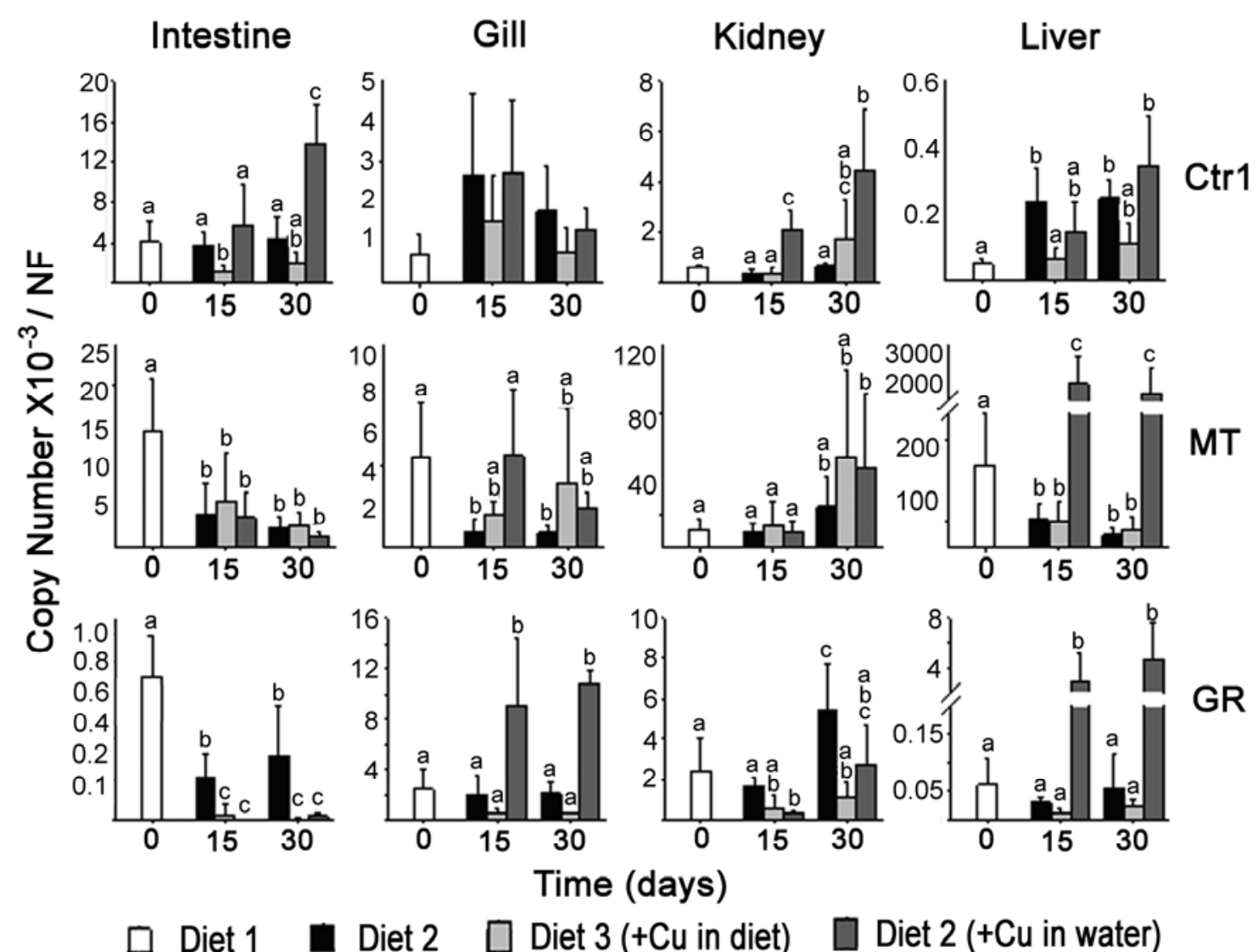

Figure 4. Tissue- and copper-specific regulation of sea bream Ctr1, MT and GR mRNA. Ctrl, MT and GR mRNA levels were measured in fish after 15 and $30 \mathrm{~d}$ fed an experimental $\operatorname{diet}\left(7.7 \pm 0.3 \mathrm{mgKg}^{-1} \mathrm{Cu}\right.$, Diet2), or a diet containing excess copper (130mgKg-1, Diet3), or after exposure to excess waterborne copper $\left(0.3 \mathrm{mgL}^{-1}\right.$, Diet $2+\mathrm{Cu}$ in water). Fish at day 0 had been maintained on a normal commercial diet $\left(12.6 \pm 0.2 \mathrm{mgKg}^{-1} \mathrm{Cu}\right.$, Diet1). Ctr1, MT and GR copy numbers were normalized by geNorm using a normalization factor (NF) based on the geometric mean of $\beta$-actin, EF1 $\alpha$ or GAPDH reference genes. Values are means \pm S.D. $N=5$. Bars bearing different lettering are significantly different $(\mathrm{P}<0.05$; ANOVA, Tukeys test). 